\title{
The Team Leadership Summit: Culminating the Leadership Experience
}

\author{
Lori L. Moore \\ Associate Professor \\ Department of Agricultural Leadership, Education, and Communications \\ Texas A\&M University \\ Summer F. Odom \\ Assistant Professor \\ Department of Agricultural Leadership, Education, and Communications \\ Texas A\&M University \\ Barry L. Boyd \\ Associate Professor \\ Department of Leadership, Education, and Communications \\ Texas A\&M University
}

\begin{abstract}
Documenting student progress related to learning outcomes is quickly becoming standard practice in higher education. This application brief describes the Team Leadership Summit assignment used in a senior seminar course. Students are required to work in teams to identify a critical issue facing society today requiring leadership and work together to discover potential solutions to the issue. Completed assignments indicate the Team Leadership Summit assignment is providing students with a project-based learning activity that gives them the opportunity to become more familiar with the role of leadership in managing, and even changing, complex organizational, community, and societal issues. The assignment is also effectively demonstrating student progress related to the seven Undergraduate Learning Outcomes identified by Texas A\&M University.

\section{Introduction}

Learning outcomes are a popular theme in higher education. "Students, employers, accrediting agencies, and those financing higher education increasingly challenge educators to demonstrate learning outcomes worthy of their substantial investments" (Schwering, 2015). Stakeholders, especially employers, expect students who have completed an undergraduate degree have the ability to integrate and apply the knowledge they have gained through their studies (Schwering, 2015). Texas A\&M University has identified seven Undergraduate Learning Outcomes "to express the results we expect undergraduates to gain through their educational experiences" (Texas A\&M University, 2015):
\end{abstract}

- Master the depth of knowledge required for a degree;

- Demonstrate critical thinking;

- Communicate effectively;

- Practice personal and social responsibility; 
- Demonstrate social, cultural, and global competence;

- Prepare to engage in lifelong learning; and

- Work collaboratively. (p. 1)

As noted in the National Leadership Research Agenda 2013-2018 (Andenoro et al., 2013), Leadership Education "is the pedagogical practice of facilitating leadership learning in an effort to build human capacity and is informed by leadership theory and research" and "is concerned with a focus on teaching and learning" (p. 4). This leaves leadership educators with the responsibility of designing undergraduate leadership degree programs that incorporate appropriate content delivered via effective methods to help students meet established learning outcomes. This paper focuses on one instructional method, problem-based learning (PBL), that can be effective at documenting student progress toward established learning outcomes.

\section{Review of Related Scholarship}

Research has documented the need for a capstone course in undergraduate leadership degree programs (Morgan, King, Rudd, \& Kaufman, 2013). The pedagogy used in capstone courses in undergraduate leadership degree programs likely varies. Regardless of the instructional method(s) used, these courses should provide students with the opportunity to integrate their knowledge across the various facets of the leadership discipline as well as demonstrate critical thinking in and about the discipline. "Psychological research and theory suggest that by having students learn through the experience of solving problems, they can learn both content and thinking strategies" (Hmelo-Silver, 2004, p. 235). PBL is an experiential approach to learning in which students learn by solving complex real-world problems that do not have a single correct answer (Hmelo-Silver, 2004). In PBL, Students work in small collaborative groups to identify what they need to learn in order to solve a problem. They engage in selfdirected learning (SDL) and then apply their knowledge to the problem and reflect on what they learned and the effectiveness of the strategies employed (Hmelo-Silver, 2004, p. 235).

As Desai, Tippins, and Arbaugh (2014) noted, PBL allows students to use "discovery and analysis to solve ill-structured real-world problems" (p. 259) as opposed to working on and through information provided by the instructor.

Project-based learning is a type of PBL in which students learn by completing a project. Desai et al. (2014) shared that "to be effective, learning and teaching methods for traditional-age undergraduates need 'activate' organizational contexts that the typical student lacks in personal experience" (p. 258). Project-based learning can meet this requirement by providing students in a capstone course with the opportunity to investigate and develop potential solutions to a meaningful problem while integrating their knowledge of leadership. Schwering (2015) identified six general or "meta" education goals common to project-based capstone courses, regardless of discipline:

Goal 1: Focus learning on problems or opportunities in real world contexts, Goal 2: Challenge students to select and apply relevant theory/knowledge, Goal 3: Integrate knowledge and multiple theoretical perspectives, Goal 4: Promote individual personal growth, 
Goal 5: Develop leadership and team process skills, and

Goal 6: Create an experience that serves as a rite of passage. (p. 93)

While the need for and the goal of capstone courses might be well documented in the literature, what to include in and how to teach such a course is often left up to the individual leadership educator teaching the course. While traditional instructional methods and pedagogical models have the potential to be effective (Schwering, 2015), these methods tend to be more teacher-centered as opposed to learner-centered, thus focusing more on "teacher delivery rather than on student learning" (Shepherd \& Cosgriff, 1998, p. 349). Furthermore, as Riggio, Ciulla, and Sorenson (2003) pointed out, experiential learning in leadership studies is critical as leadership is an applied discipline.

Not all students are the same, and best practices of teaching have led many leadership educators to believe that actively engaging students in the learning process is critical. Utilizing teaching pedagogies that require active engagement by students has been shown to decrease the gap between academically inclined students and those who may not be academically inclined, but rather are in college simply to obtain a good job following graduation (Biggs \& Tang, 2011). Because PBL involves real-world problems, leadership educators can implement PBL in their capstone courses to encourage active engagement from all types of students as they apply what they have learned in previous courses.

Regardless of the instructional method employed, student learning must still be evaluated. Traditional methods, such as exams, "while suitable for evaluating cognitive knowledge, may not fully capture students' abilities to transfer and apply leadership related knowledge and skills into real-world practice" (Goertzen, McRay, \& Klaus, 2016, p. 42). Riggio et al. (2003) even stated, "leadership is a discipline where it is particularly important that students receive some form of structured opportunities to apply theories and concepts in the classroom" (p. 239).

The first priority of the National Leadership Research Agenda 2013-2018 (Andenoro et al., 2013) is Teaching, Learning, and Curricular Development. This priority called for the development of transdisciplinary perspectives and curriculum development frameworks that enhance transfer of learning. Clearly the "meta" goals of capstone courses (Schwering, 2015) require students to synthesize, integrate, and apply what they have learned in previouscourses. Unfortunately, some educators encounter "students in senior-level courses that are open to receiving new knowledge without bringing sufficient know-how from prerequisite courses to the learning environment" (Raska, Keller, \& Shaw, 2014). Leadership educators at Texas A\&M University have adopted the concept of summit meetings as the context for a PBL assignment to help students review and utilize previously learned leadership concepts and theories and apply this previous learning to a real-world problem, thus demonstrating progress toward multiple Undergraduate Student Learning Outcomes (Texas A\&M University, 2015) such as "mastering the depth of knowledge required for a degree" and "demonstrating critical thinking" (p.1).

Summits are often associated with a meeting or series of meetings between the leaders or the Heads of State of two or more governments. However, the concept can be extended to describe gatherings of people, such as high-level executives or leaders that are deeply interested 
and/or concerned with the same subject or issue. Baker and Rhea (2009) described a summit as "a strategic conversation that brings different perspectives within a system together to talk about the big picture and big questions" (Baker \& Rhea, 2009, Not Just Any Meeting section, para. 1). Summits often lead to the creation of common ground and action plans that incorporate new ideas and approaches. Booz Allen Hamilton (n.d.) noted, "Summits often serve as a mechanism to facilitate a deeper understanding of a problem and to generate a plan of action through strategic conversations with high-level leaders from organizations across the country" (p. 2).

Summits provide a context for promoting leadership development and team process skills. Booz Allen Hamilton (n.d.) identified six key attributes for successfully planning and executing summit meetings:

- Identify a challenge;

- Create a focused agenda;

- Provide an intimate setting;

- Determine concrete outcomes;

- Produce sustained improvement; and

- Evaluate program outcomes.

\section{Description of the Practice}

The senior seminar course at Texas A\&M University is a capstone course intended to help students review, integrate and apply what they learned through previous coursework. Utilizing the conceptualization of summits for creating an environment for strategic conversations that can guide participants to a deeper understanding of a subject matter, leadership educators at Texas A\&M University created and implemented the Team Leadership Summit assignment within the senior seminar course.

The Team Leadership Summit assignment requires students to focus simultaneously on process and product. Students are divided into teams of five to eight students, depending upon the total enrollment. Drawing upon each team member's unique perspective, knowledge, skills, and abilities, they are asked to identify and address what they consider to be a critical issue requiring leadership as a solution. More specifically they are asked to: foster collaborative initiatives, inspire action to address a complex problem, focus on problem-solving outcomes for their issues; generate solutions to key issues, and identify concrete action plans. Teams are provided time each week to focus on their summit and submit accountability reports throughout the semester.

At the end of the semester teams submit a written final report and orally present their findings to the class. The final report consists of a one-page executive summary and an after action report of their summit. The executive summary, distributed to each member of the class, introduces their issue, the facts surrounding the issue, decisions the team made based on the facts, and recommendations the team has for moving forward. The after action report includes the following sections: 
- Summit Overview: a summary of the problem or issue;

- Introduction and Background: facts about the summit topic that can be supported with facts and/or statistics to illustrate both the need for and the history of the issue being addressed;

- Solutions: solutions to key issues identified;

- Action plans: including strategies and resources; and

- Food for Thought: a description of the overall summit process and lessons learned.

The seven Undergraduate Learning Outcomes (Texas A\&M University, 2015) serve as the foundation for how Team Leadership Summit assignments are graded. Team accountability reports, the final report, and the team oral presentation are artifacts used to evaluate performance in each of the seven outcomes included on the assignment rubric. Criteria for each of the seven outcomes were adapted from multiple VALUE (Valid Assessment of Learning in Undergraduate Education) rubrics developed as part of the Association of American Colleges \& Universities (AAC\&U) Liberal Education and America's Promise (LEAP) initiative. The VALUE Rubric Development Project page (n.d.) of the AAC\&U website notes that "the VALUE rubrics contribute to the national dialogue on assessment of college student learning" (para. 2).

\section{Discussion of Outcomes/Results}

The Team Leadership Summit assignment was implemented in the fall 2014 semester. The assignment has since been used each semester in both face-to-face and online sections of the course. Course instructors have observed teams integrating and applying concepts from previous leadership coursework within the major as well as generating innovative solutions to their selected issue. Table 1 summarizes these concepts and the related leadership course name from selected Team Leadership Summits.

Table 1

Issues, Leadership Concepts/Theories, and Related Courses Referenced in Selected Team Leadership Summit Assignments

\begin{tabular}{|c|c|c|}
\hline Summit Issue & Leadership Concepts/Theories & Related Coursework \\
\hline $\begin{array}{l}\text { Concealed Carry on } \\
\text { Campus }\end{array}$ & - Power Bases & - Survey of Leadership Theory \\
\hline Bullying & $\begin{array}{ll}\text { - } & \text { Relational Leadership Model } \\
\text { - } & \text { Kidder's } 9 \text { Checkpoints for } \\
\text { Ethical Issues }\end{array}$ & $\begin{array}{l}\text { - Introduction to Leadership } \\
\text { - Ethics }\end{array}$ \\
\hline Illegal Immigration & $\begin{array}{ll}\text { - } & \text { Ethical Dilemmas } \\
\text { - } & \text { Stages of Moral } \\
& \text { Development } \\
\end{array}$ & $\begin{array}{l}\text { - Introduction to Leadership } \\
\text { - Ethics }\end{array}$ \\
\hline Food Deserts & $\begin{array}{l}\text { - } \quad \text { Relational Leadership Model } \\
\text { - } \quad \text { Change Models }\end{array}$ & $\begin{array}{l}\text { - Introduction to Leadership } \\
\text { - Leading Change }\end{array}$ \\
\hline
\end{tabular}




\section{Reflections of the Practitioners}

While the Team Leadership Summit assignment has not yet been studied empirically, anecdotal evidence suggests it is effectively accomplishing each of the six "meta" educational goals of project-based capstone courses outlined by Schwering (2015). Course instructors believe the Team Leadership Summit assignment provides students with an experiential learning activity embedded within the larger capstone experience, and simultaneously gives them an opportunity to become more familiar with the role of leadership in managing, and even changing, complex organizational, community, and societal issues. Course instructors have been encouraged by the ability of teams to apply various leadership concepts and theories to the ill-defined problems they selected for their summit assignment (Schwering Goals 1, 2, and 3). They have also noted, however, that some students, especially those in the online sections of course, are initially uncomfortable with the seemingly unstructured nature of the some aspects of the assignment. Teams often experience moderate to significant frustration, especially when selecting their issue, but eventually tend to see the lack of structure as an advantage because it allows them to apply their own expertise (Goal 4). Because the assignment is completed in teams and each team is asked to focus on both process and product, teams often include a discussion of how the team worked in the Food for Thought section of their final report and within their oral presentation (Goal 5). Finally, course instructors have noticed that this assignment often helps students begin to see themselves as near-graduates who know more than they thought they knew at the beginning of the assignment (Goal 6).

Because teams are provided class time each week to work on their summits, course instructors have noticed team member holding each other accountable for class attendance and participation in ways not seen in previous courses within the major. This is further documented on the team accountability reports and is directly related to the "practice personal and social responsibility" Undergraduate Learning Outcome (Texas A\&M University, 2015).

As Schwering (2015) noted, accrediting agencies are interested in whether or not programs are effectively meeting student learning outcomes. Because the Team Leadership Summit assignment utilizes the seven Undergraduate Learning Outcomes of Texas A\&M University (Texas A\&M University, 2015) as the basis for evaluation, this assignment is currently used in the departmental assessment plans that are required for accreditation.

\section{Recommendations}

It is recommended that the Team Leadership Summit assignment be empirically studied. For example, a more detailed analysis of the decision-making strategies used in selecting the issue should be conducted as this process likely influences the overall commitment of individual team members to the summit.

This assignment is designed to actively engage all students. Additional empirical research on the level of engagement of individual team members should be conducted. Findings of such studies could provide insight into whether the assignment is successfully decreasing the gap between academically inclined and non-academically inclined students as Biggs and Tang (2011) suggest is the case with teaching strategies that actively engage all students. 
It is also recommended that the students be reminded of the Undergraduate Learning Outcomes (Texas A\&M University, 2015) in each course within the degree program to facilitate growth in each of the learning outcomes. In addition to being beneficial as a reminder for instructors, emphasizing the learning outcomes within each course offers the potential to help students communicate with future employers what they really learned within their degree program.

\section{References}

Andenoro, A. C., Allen, S. J., Haber-Curran, P., Jenkins, D. M., Sowcik, M., Dugan, J. P., \& Osteen, L. (2013). National Leadership Education research agenda. 2013-2018: Providing strategic direction for the field of leadership education. Retrieved from Association of Leadership Educators website: http://leadershipeducators.org/ResearchAgenda

Association of American Colleges \& Universities. (n.d.). VALUE rubric development project. Retrieved from https://www.aacu.org/value/rubrics

Baker, J. L., \& Rhea, M. (2009, October). Organizing a summit, step by step. Associations Now. Retrieved fromhttp:www.asaecenter.org/Resources/anowdetail.cfm?itemnumber $=45509$

Biggs, J., \& Tang, C. (2011). Teaching for quality learning at university: What the student does ( $4^{\text {th }}$ ed.). Berkshire, England: Society for Research into Higher Education \& Open University Press.

Booz Allen Hamilton. (n.d.). Framework for convening a community summit. Retrieved from http://www.boozallen.com/content/dam/boozallen/media/file/Population-Health-SummitToolkit.pdf

Desai, A., Tippins, M., \& Arbaugh, J. B. (2014). Learning through collaboration and competition: Incorporating problem-based learning and competition-based learning in a capstone course. Organization Management Journal, 11(4), 258-271. doi: 10.1080/15416518.2014.973793

Goertzen, B. J., McRay, J., \& Klaus, K. (2016). Electronic portfolios as capstone experiences in a graduate program in organizational leadership. Journal of Leadership Education, 15(3), 42-52. DOI: 1012806/V15/I3/A5

Hmelo-Silver, C. E. (2004). Problem-based learning: What and how do students learn? Educational Psychology Review, 16(3), 235-266.

Morgan, A. C., King, D. L., Rudd, R. D., \& Kaufman, E. K. (2013). Elements of an undergraduate agricultural leadership program: A delphi study. Journal of Leadership Education, 12(1), 140-155. 
Raska, D., Keller, E. W., \& Shaw, D. (2014). The curriculum-faculty reinforcement alignment and its effect on learning retention of core marketing concepts of marketing capstone students. Marketing Education Review, 24(2), 145-158. doi: 10.2753/MER10528008240205

Riggio, R. E., Ciulla, J., \& Sorenson, G. (2003). Leadership education at the undergraduate level: A liberal arts approach to leadership development. In S. E. Murphy \& R. E. Riggio (Eds.), The Future of Leadership Development (pp. 223-236). Mahwah, New Jersey: Lawrence Erlbaum Associates.

Schwering, R. R. (2015). Optimizing learning in project-based capstone courses. Academyof Educational Leadership Journal, 19(1), 90-104.

Shepherd, A., \& Cosgriff, B. (1998). Problem-based learning: A bridge between planning education and planning practice. Journal of Planning Education and Research, 17(4), 348-357.

Texas A\&M University, Office of the Associate Provost for Undergraduate Studies. (2015). Undergraduate Learning Outcomes. Retrieved from http://provost.[university].edu/e ssentials/pdfs/copy_of_UndergraduateLearningOutcomesFinal.pdf

\section{Author Biographies}

Lori L. Moore is an Associate Professor in the Department of Agricultural Leadership, Education, \& Communications at Texas A\&M University. She teaches undergraduate and graduate courses in introductory leadership, leadership theory, and methods of teaching. She is the co-coordinator of the university-wide freshman Leadership Living Learning Community (L3C). Dr. Moore's research focuses on leadership pedagogy and the intersection between leadership education and leadership development in collegiate leadership programs.

Summer F. Odom is an Assistant Professor in the Department of Agricultural Leadership, Education, \& Communications (ALEC) at Texas A\&M University. She teaches courses in personal and professional leadership. Dr. Odom received her Ph.D. in Human Resource Development in May 2011. Her research interests include leadership and life skill capacity building of young adults with a focus on collegiate leadership education, assessment and evaluation of leadership pedagogy, and intrapersonal leadership development.

Barry L. Boyd is an Associate Professor in the Department of Agricultural Leadership, Education, \& Communications at Texas A\&M University. He is a member of the Fighting Texas A\&M Class of '82 and earned his Ph.D. from Texas A\&M in 1991. He teaches courses in personal leadership development, and applied ethics. Dr. Boyd's research focuses on transformational teaching, assessment of student learning, and teaching for critical thinking in the classroom. In addition, he co-coordinates the Critical Thinking Academy in the College of Agriculture \& Life Sciences. 